\title{
Environmentally Induced Alternative Livelihood Strategies among the Artisanal Fishers of the Kainji Lake Basin, Nigeria
}

\author{
A. A. Tafida and M. Galtima
}

\begin{abstract}
In Nigeria, the fisheries sub-sector has been dominated by small-scale artisanal fishers who live in communities that are characterized by high levels of poverty and food insecurity aggravated by overexploitation and depletion of the fishery resources, and other environmental problems. Kainji Lake has suffered reduced inflow levels from $393,369 \mathrm{~m} / \mathrm{cu} 3$ in 1994 to $307,231 \mathrm{~m} / \mathrm{cu} 3$ in 2011 . Similarly, the fish yield dropped from 27,501metric tons in 1994 to 3,476 metric tons in 2011, which jeopardized the livelihoods of hundreds of thousands of stakeholders. The objective of this work was to develop an adaptive strategy model using the concept of sustainable livelihoods approach. Data were largely obtained through a field survey (using questionnaire) in $\mathbf{3 0}$ fishing communities, and supplemented by data from other authorities. The results showed that a combination of four livelihood activities is the optimum. The implications of the work are discussed.
\end{abstract}

Index Terms-Environment, fishermen resilience, Kainji Lake, livelihood strategy, resource sustainability.

\section{INTRODUCTION}

Small-scale fisheries are most critically affected by environmental factors and the management practices adopted. In many parts of the world, the supporting ecosystems have been poorly managed and the economic losses due to overfishing, pollution and habitat loss have been estimated to exceed \$50billion annually [1]. This according to [2], have made the livelihoods of more than 520million people (about $8 \%$ of the world's population) who depend on fisheries and aquaculture as a source of protein, income and family stability vulnerable. Many of these people are found to live in developing countries amidst abject poverty conditions. In Nigeria, the Kainji Lake, like most other man-made lakes, is of great economic and environmental importance to the riparian communities and the nation at large. Apart from its primary purpose of generating hydro-electricity, it is used for different 'purposes, which include domestic, fishing, navigation and irrigation. Over the years, the pattern of both rainfall and discharge of the Lake have varied tremendously and remains a source of concern to the stakeholders in particular the fishers, as it affects fish yield and their livelihoods. The variation in Lake Kainji and accompanied changes in fish yield have consequently resulted in subjecting

Manuscript received February 1, 2015; revised April 29, 2015.

A. A. Tafida is with Agricultural Economics and Extension Department, Modibbo Adama University of Technology, PMB 2076 Yola, Nigeria (e-mail: tafjam2003@yahoo.com).

M. Galtima is with Geography Department, Modibbo Adama University of Technology, PMB 2076 Yola, Nigeria. the major actors (fishers) into poverty conditions.

It has been asserted that for the prospects and improvement of fisheries, established theories, approaches, definitions of sustainability, and indicators of management performance have to be re-thought. One important way to address these impacts is to develop a strategy for adaptation and resilience through diversity of livelihood portfolios [3]-[5]. A consensus has long emerged across disciplines (ecology, social sciences) that emphasize the necessity to build fisheries management around the concepts of resilience and adaptive management [6], [7]. More formally, resilience analysis proposes to focus on mechanisms and processes that help systems absorb perturbations and shocks, and cope with uncertainty and risks. Defined in such a way, the concept of resilience thus appears particularly useful for the management of small-scale fisheries. Therefore, the study becomes imperative to inform policy on the implications of decline in fisheries following the variation in the hydrological regime. The objective is to examine the effects of variation in hydro-climatic variables on fisheries and the fishers and to develop an adaptive strategy model for sustainable livelihood among the artisanal fishers.

\section{The STUdy AREA AND Methods}

\section{A. The Study Area}

The study was conducted in Kainji Lake, located between longitude $9^{0} 50^{\prime}-10^{0} 55^{\prime} \mathrm{N}$ and Latitude $4^{0} 43^{\prime}-4^{0} 45^{\prime} \mathrm{E}$. It is the largest manmade lake in Nigeria created in 1968 following the impoundment of River Niger by the construction of the Kainji Dam at New Bussa. The Dam was created for hydroelectric power generation to boost industrial growth and general economic development in the country. However, the reservoir created secondary economic opportunities, in particular fishing activities. Kainji Lake gets its water mainly from River Niger, which takes its source from the Fouta Djallon highlands, and from local rivers around the lake basin. The Lake covers an area of $1,250 \mathrm{~km}^{2}$, and a maximum depth of $54.9 \mathrm{~m}$ and extends to $136.8 \mathrm{~km}$ upstream to Yelwa area. The widest point is $24.1 \mathrm{~km}$ (its water fluctuates between $10-11 \mathrm{~km}$ annually with a surface temperature of $23-31^{\circ} \mathrm{C}$ and catchment area of $1.6 \times 10 \mathrm{~km}^{2}$ [8]. The river Niger has two flood regimes; the black floods and white floods. Water originating from the source area of the Niger and its catchments travel a distance of $4,183 \mathrm{~km}$ to reach the lake 6 months later; on its way, the water drains the swamp of Timbuktu where it loses $65 \%$ of its volume to evaporation and infiltration. Having deposited itself in three swampy areas the 
water becomes clean and appears black from a distance look on its arrival at the lake, hence it's called black flood (December to March) and recedes in May-August when the white flood takes over. The white flood originates from August to November annually. It carries lots of silt and mud giving it the milky look. The flood reaches its peak about September and is much higher than that of the black flood. It has a peak discharge of 4,000 cubic meters per seconds and levels down to 1,500 cubic meters per second in November when the black flood takes over again [9]. The existence of two hundred and ninety seven (297) permanent fishing villages and camps and one (1) temporary fishing camp around the lake basin and the Islands has been documented [10].

\section{B. Socio-Economic Background of the People}

Some studies on the Lake basin revealed the socio-economic characteristics of the people to comprise of the following; majority of the fishermen are Sarkawa sub tribe of the Kebbi Hausa, with other tribes like Laru, Gungawa, Lopawa, Nupes. Majority of them are illiterates [11]. People of Hausa and Nupe origin are full time professional fishermen, and most recently they are engaged in farming, livestock rearing, petty trading etc. [5], [12]. According to [11] the Hausa's monopolized the occupation due to their long attachment to it. Other professional fishermen are Zabarmawa, who originated from Mali and Niger Republics. Traditional occupations of the people apart from fishing include, farming, livestock and local enterprises such as pottery, mat weaving, gear/craft making and servicing etc [13], [14].

\section{Data, Sampling Technique and Analysis}

The study relied on both primary and secondary data sources, micro level data were collected from 259 households in 30 fishing villages around the Lake Basin using stratified sampling technique and the elements were drawn through simple random sampling. The data was collected twice in January/February and August/September, representing two distinct water flow regimes (high and low), which determines the abundance and scarcity of fish and equally coincides with dry and rainy seasons in order to capture seasonality and variability in income and expenditure. The secondary data was colleted from the National Institute for Freshwater Fisheries Research New Bussa, and the missing data were filled through extrapoliation. Descriptive statistics was used by comparing means of different livelihood enterprise combinations. A mean income for each livelihood enterprise combination was estimated using the following formula:

$$
\bar{Y}_{i, . ., k}=\frac{\sum_{i=1}^{k} Y_{i}}{n}
$$

where $Y_{i, ., n}^{-}$is the mean income for households with enterprises $i$ to $k$ where $\mathrm{k}$ is the total number of enterprises a household is engaged in, $Y_{i}$ is the income from enterprise $n$ and $I$ is total number of households with the given livelihood enterprise combination.

\section{RESULTS AND DISCUSSION}

\section{A. Hydro-Climatic Variations in the Kainji Lake Basin}

The river Niger, which, is the main source of water to Lake Kainji has undergone two major hydrological changes over the years. The inter annual inflow and outflow changes in Lake Kainji has been observed for 18 years from 1994 to 2011. The results in Fig. 1, showed high annual inflow (upstream) variability and subsequently reflects on the year to year variation in the outflow (down stream); discharge depends primarily on rainfall and inflow from the upstream. The changes have some direct effects on the fish environment and subsequently its productivity. Potential benefits may be offset by a range of factors including reduced spawning success of river fishes because of higher wet season river flows, reduced fish survival in lower dry season flows, and loss of habitat to new engineering projects and other human responses. According to [15] fish reproduction, growth and mortality are affected by precipitation and evaporation changes on hydrology of inland waters. This corroborated the report of [16], as observed in Lake Mwemu and Lake Turkama, where fish catch declines when the Lake level is low, an indication that water level determines stock fluctuation to a large extent. Overall, the productivity of a fishery is tied to the health and functioning of the ecosystems on which it depends for food, habitat and even seed dispersal [17].

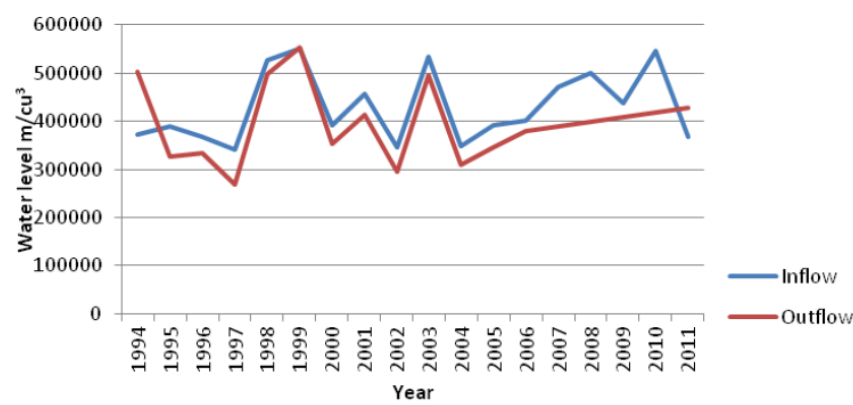

Fig. 1. Anomalies of the water inflow and outflow in Kainji Lake 1994-2011.

One of the hydrological data regularly collected in the lake basin is rainfall data. The rainfall pattern in Kainji Lake for 18 years beginning 1994 has been found to show great variability (Fig. 2). Minimum rainfall of $735.3 \mathrm{~mm}$ was recorded in 2002; the maximum was $1349.8 \mathrm{~mm}$ recorded in 1998 , with average of $1043.18 \mathrm{~mm}$. Between the two extremes, the rainfall varied monthly and between years and therefore shows annual and long-term variability. In both ways, variability in rainfall causes changes in water level and physio-chemical parameters, which have direct influence on fish yield. Low water level hinders navigation, yet water quality problems are expected to be increased in periods of low discharge as concentration of nutrients and pollutants will increase [18]. Decrease in fish yield remains one of the major sources of vulnerability faced by the fishers. Therefore, the effects of hydrological variation on both fish and food production and livelihoods of people seem to be critical and require urgent address. 
Similarly, Fig. 3 shows variability and in some years high temperatures. The highest temperature of $41.22^{\circ} \mathrm{C}$ was recorded in 1999 while the least of $36.41^{\circ} \mathrm{C}$ was recorded in 2007 , with an average of $38.2^{\circ} \mathrm{C}$. Fish reproduction is often highly sensitive to fluctuations in temperature [19]. Higher temperatures may reduce the availability of wild fish stocks, by harming water quality, worsening dry season mortality, bringing new predators and pathogens, and changing the abundance of food available to fishery species [20]. Fish also tend to live near their tolerance limits of a range of factors; as a result, increased temperature and acidity, lower dissolved oxygen and changes to salinity can have deleterious effects [21].

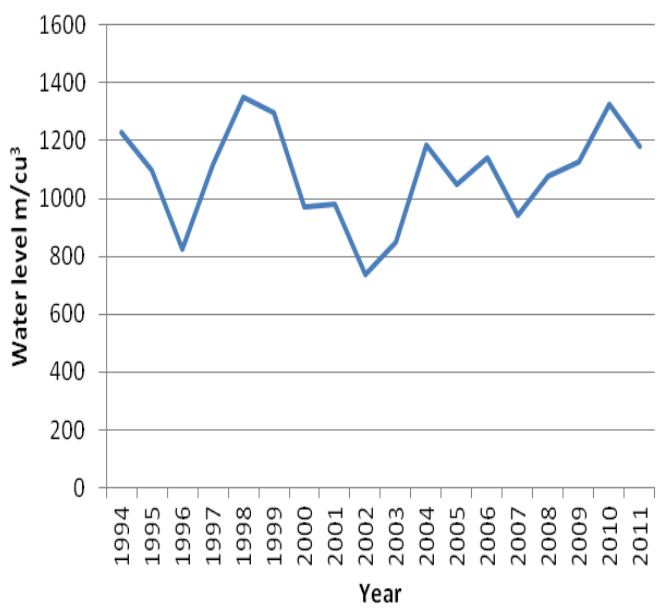

Fig. 2. Anomalies of the annual rainfall in Kainji Lake 1994-2011.

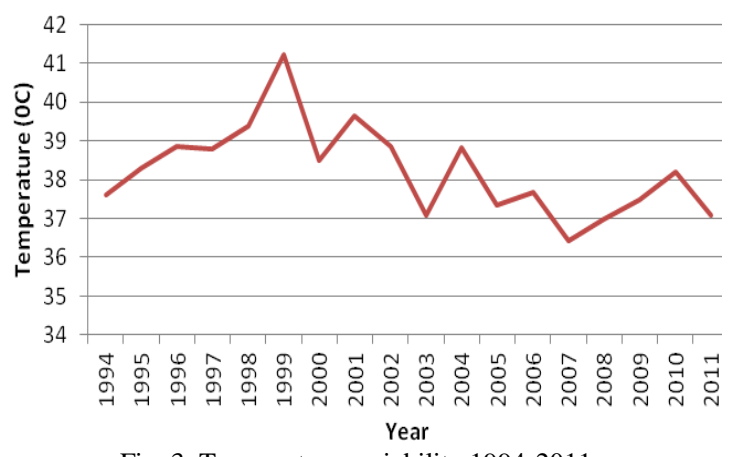

Fig. 3. Temperature variability 1994-2011.

\section{B. Effects of Hydro-Climatic Changes on Fish Yield}

Fig. 4 shows the changes occurred in terms of fish yield over the years. The variation in the yield showed an alarming drop from 38,346 metric tons in 1996 to 11,315 tons in 2002 and to just about 3,476 tons in 2011. This is as a result of variability in inflow, outflow and rainfall and temperaure and may be due to poor management practices such as, over exploitation, application of obnoxious fishing methods in the area. However, among all the attributes that contribute to low fish yiled, low water level remains the most critical factor. Strong linkages exist between changes in climatic parameters such as temperature, rainfall and fisheries productivity. Extreme temperature and changes in precipitation lead to lower water level. Meanwhile, lower water level alters spawning and recruitment of endemic fish species and also, lead to lower quality due to reduced productivity capacity of photosynthesis balance. Changes in water level and quality affects fish reproductive patterns and migratory routes while precipitation changes affects fish reproduction, growth and mortality. Generally, this will lead to low yield and by implication low income, food insecurity and poor health among others. According to [20] changes in precipitation averages and potential increases in seasonal and annual variability and extremes are likely to be the most significant drivers of changes in inland fisheries. This has a great effect on livelihoods of the people, particulary looking at the population increase in the basin area and the Nigeria at large.

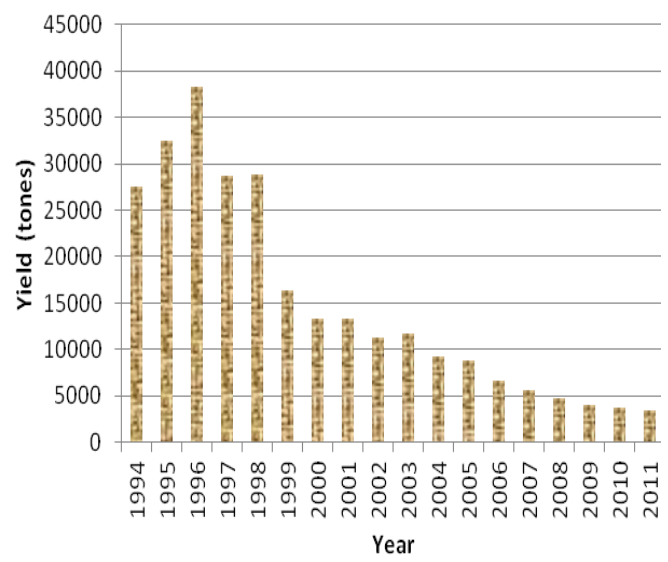

Fig. 4. Fish yield in the study area 1994-2011.

\section{Adaptation and Coping Strategy Model}

The environmental changes as a result of variability in precipitation and water inflow and outflow to Lake Kainji and its consequential depletion in fish yield over the years, made the fishers to adjust in certain ecological, social and economic system in order to alleviate the adverse impacts of change and take advantage of certain opportunities based on the availability of assets around them to construct other livelihood activities. Thus, this study developed a model for optimum livelihood strategies adopted. The model identified the contribution of each livelihood activity engaged by the fishers to their overall income.

The results revealed that income from non-fishing enterprises make up an increasing proportion of overall income for most households in Kainji Lake fishing communities. From Fig. 5, fishing and fish processing contribute up to $68.8 \%$ of the total income (44.9\% for fishing and $23.9 \%$ for fish processing). Other non-fishing activities like crop production form the next most important contribution to household income with $15.8 \%$ of the total income and is followed by livestock with $12.4 \%$. Trading contributed the least with $3.1 \%$. This result is similar to a study in the Zambezi Floodplain, which revealed that inland fisheries generated more cash for households than cattle rearing in most cases and in some cases more than crop production [22]. While majority of the fishers in the Kainji Lake basin are diversifying in response to the changes in fisheries resources, the diversification trends are demonstrably the same across most communities, probably due to similarities in other resource e.g. availability of land for farming and cultural affiliation of the people in rearing livestock and skills. However, of recent trading and other servicing activities are widely spreading across the fishing communities. [23], reported that increased earnings of all household members were such as the primary route out of 
poverty. The idea behind livelihood diversity is that irrespective of seasonality of their various economic activities, fishing households would always have access to one source of income or the other following their diversity of livelihood portfolios, which serves as a buffer against household vulnerability, thereby guarantees improved well-being of the family.

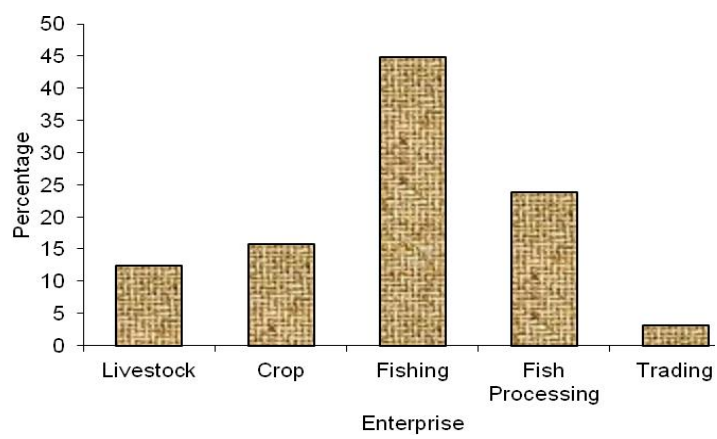

Fig. 5. Contribution of various activities to the overall income.

\section{Best Activity Combination Model}

Five groups of different enterprises combination in the fishing communities were identified; this was later subjected to a descriptive statistics and compared with the mean income for each livelihood activity combination. The result shows that the fishing households that combine four enterprises have more income, with mean of $\$ 6227.42$, followed by five enterprises with mean income of $\$ 3955.31$. The least is those that have only two activities (see Table I). Therefore, it is recommended that fishing households should engage in four to five enterprises rather than two. This essentially will allow them to reduce fishing effort and thereby sustain the resources for future generation. The importance of this model for livelihood activity combination lies in its function of addressing two issues; enhancing income and well-being of the actors and bringing about fisheries resource sustainability through reduction of fishing efforts, thereby addressing the age long problem of fisheries resource management in the area. One of the keys to successful adaptation is diversification-the more options that communities have to produce, process, and distribute- the greater the chance that some of them may be favoured or not affected by climate change [24]. According to [25] adaptation is an active set of strategies and action taken by people in response to, or in anticipation to the change in order to enhance or maintain their well-being.

TABLE I: LIVELIHOOD ENTERPRISE COMBINATION (DESCRIPTIVE STATISTICS)

\begin{tabular}{|c|c|c|c|c|c|c|}
\hline & $\mathbf{N}$ & Minimum & Maximum & Sum & Mean & $\overline{\text { Std. Deviation }}$ \\
\hline mean income from hh with one enterprise & 248 & .00 & 288000.00 & 535200.00 & 2158.07 & 20387.84 \\
\hline mean income from hh with two enterprises & 248 & .00 & 37352.38 & 424257.14 & 1710.71 & 6277.43 \\
\hline Mean income from hh with three enterprises & 248 & .00 & 20459.18 & 629537.55 & 2538.46 & 3865.13 \\
\hline mean income from hh with four enterprises & 248 & .00 & 48400.00 & 1544400.64 & 6227.42 & 8114.95 \\
\hline mean income from hh with five enterprises & 248 & .00 & 194818.18 & 980918.18 & 3955.32 & 20244.73 \\
\hline
\end{tabular}

hh=household

\section{CONCLUSION}

Climate change is affecting the aquatic habitat, the fishery resources and livelihoods of both the primary stakeholder (fishers) and myriads of others benefiting actors along the value chain. Beside the ecological problems identified, management problems such as overfishing, exploitation and pollution accentuate the problems by reducing annual fish yield and other economic benefits, thereby subjecting the fishers into abject poverty. The current livelihood strategies model is developed to consolidate the adaptive strategy being used by the fishing communities to avert the ecological vulnerability and to improve their socio-economic well-being. Policies targeted at improving fisheries development in Nigeria should look at both ecological and management aspects in order to attain greater sustainability.

\section{REFERENCES}

[1] World Bank and FAO (2008). The sunken billions: The economic justification for fisheries reform. Agriculture and Rural Development Department. [Online]. Available: www.worldbank.org.sunkenbillions

[2] E. Allison, "Reducing global and national vulnerability to climate change in the fisheries sector: Policy perspectives post Copenhagen," Japan, 2010, p. 5.

[3] F. Ellis, "Rural livelihood diversity in developing countries: Evidence and policy implications," Odi Natural Resources Perspective, no. 40, April 1999, p. 40.

[4] C. Bene, "Contribution of small-scale fisheries to rural livelihoods in water multi-use context with a particular emphasis on the role of fisheries as the last resort activity for the poor," presented at the Second Session of the FAO Working Party on Small Scale Fisheries, Bangkok Nov. 18-21, 2003, pp. 1-4.

[5] A. A. Tafida et al., "Assets accessibility and its relevance to Livelihood diversity and poverty alleviation among the artisanal fishers in Kainji Lake basin Nigeria," Nigerian Journal of Fisheries Technology, vol. 1 , no. 2, pp. 61-66, 2010.

[6] S. R. Carpenter et al., "From metaphor to measurement: Resilience of what to what?" Ecosystems, vol. 4, pp. 765-781, 2001.

[7] B. Walker et al., "Resilience management in social ecological systems: A working hypothesis for a participatory approach," Conservation Ecology, vol. 6, 2002.

[8] L. R. Welcome, The Inland Water of Africa CIFA/TI FAO, Rome, 1972 .

[9] NEDECO and Balfour Beatty, Niger Dams Project Vol. 1 and the Hagner, NEDECO London, 1961.

[10] J. A. Abiodun and A. M. Niworu, "Fisheries statistics bulletin, Kainji Lake fisheries management and conservation unit," Technical Report, Oct. 2004

[11] J. O. Ayanda and S. O. Alamu, "Preliminary investigation into the development and impact of fishermen's organization in the Kainj Lake basin," National Institute for Freshwater Fisheries Research Annual Report, pp. 195-204, 1991.

[12] J. K. Okomoda, "A qualitative study to identify alternative sources of income for fisher folks of Kainji Lake basin," NIFFR Annual Report, p. $194,1995$.

[13] S. O. Alamu and M. Mdaihli, Evaluation of Formal and Informal Loan Schemes Existing in Kainji Lake National Institute for Freshwater Fisheries Research Annual Report, pp. 188-193, 1995.

[14] I. G. Mbagwu and S. I. Ovie, Descriptive Analysis of the Environmental Quality and Habitat Value of Kainji Lake National Institute for Freshwater Fisheries Research Annual Report, pp.13-14, 1999.

[15] E. H. Allison et al., "Effects of climate change on the sustainability of capture and enhancement fisheries important to the poor: Analysis of 
the vulnerability and adaptability of fisherfolk living in poverty," Department for International Development (UK) Project Number R4778J, 2005.

[16] Worldfish Center, The threat of fisheries and aquaculture from climate change," World Fish Center Policy Brief, 2007.

[17] Multi-Agency Brief. (2009). Fisheries and Aquaculture in a Changing Climate. [Online]. Available: ftp://ftp.fao.org/FI/brochure/climate_change/policy_brief.pdf

[18] The Institute for Water Education, "Dialogue on water and climate," Institute for Water Education (IHE) Delft, the Netherlands (UNESCO-IHE), 2003.

[19] P. L. Munday et al., "Climatic change and the future for coral reef fishes," Fish and Fisheries, vol. 9, pp. 261-285, 2008.

[20] Worldfish Center, "The threat of fisheries and aquaculture from climate change," World fish center Penang Malaysia, 2006.

[21] J. M. Roessig et al., "Effects of global climate change on marine and estuarine fishes and fisheries," Reviews in Fish Biology and Fisheries, vol. 14, pp. 251-275, 2004.

[22] C. Bene, "Small scale fisheries: Assessing their contribution to rural livelihoods in developing countries," FAO Fisheries Circular 1008, Food and Agriculture Organization, Rome, 2006.

[23] M. J. Bane and D. T. Ellwood, "Slipping into and out of poverty; the dynamics of spells," The Journal of Human Resources, vol. 18, pp. 81-103, 2004.

[24] J. Bell et al., Preliminary Assessment of the Effects of Climatic Change on Fisheries and Aquaculture in the Pacific, 2011.

[25] B. Mohanty et al., "Climate change: Impacts on fisheries and aquaculture, climate change variability," 2010.

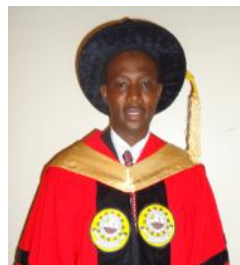

Ahmadu Abubakar Tafida was born in Kaltungo in 1970. He attended the Federal University of Technology, Modibbo Adama University of Technology Yola, Adamawa State Nigeria, where he earned a B.Tech. in agricultural economic and extension in 1997 and the M.Sc. and the Ph.D both in rural development, in 2002 and 2010 respectively.

$\mathrm{He}$ had worked as a socio-economic research officer at the National Institute for Freshwater Fisheries Research New Bussa between 2001 and 2012. He also worked with Ectad-FAO United Nations Abuja, as a national consultant livelihood specialist in 2009. He participated in various international projects including DFID/FAO-SFLP Tatabu
Community Project for poor women fish processors; BMZ International Project on Poverty Alleviation through Improved Valuation and Governance in Niger River fisheries and CP 72 CGRIAR project on Participatory Diagnosis and Adaptive Management in Niger River Fisheries. He has attended several international courses abroad among which include facilitating multi-stakeholders processes and social learning at Wageningen University and Research, the Netherlands, 2007. He is currently a lecturer in the Department of Agricultural Economic and Extension at the Modibbo Adama University of Technology Yola. His current research interest is in the area of sustainable livelihoods and poverty with particular reference to rural people who depend on natural resources for their survival.

Dr Tafida is a member of Fisheries Society of Nigeria and Human Development and Capability Association (Oxford). He got a fellowship award from the Netherlands Government (NFP) in 2007.



Mala Galtima was born in Maiduguri, Nigeria, on December 5, 1962 and was educated at Government College Maiduguri between 1975 and 1980. He proceeded to the University of Maiduguri in 1981, where he obtained bachelors degree in geography with honors in second class upper division. In 1988 he attended the University of Lagos where he studied his masters degree in geography with specialization in transport and urban analysis. Galtima was a visiting research student at the Department of Aeronautical Engineering \& Transport Studies, Loughborough University of Technology, United Kingdom in 1995. He obtained the Ph.D. degree in geography (transportation planning) from the University of Ilorin, Ilorin, Nigeria.

$\mathrm{He}$ is a professor of geography at the Modibbo Adama University of Technology, Yola, Nigeria, and has served in many capacities including the Chair of Geography and the Dean of the School of Environmental Sciences between 2005 and 2014. Galtima has co-edited books among which include 'The Land and the People of Mambilla Plateau' Heneimann Edducational Books, Plc. His current research interests are in the areas of Environment and Livelihood Vulnerability studies.

Professor Galtima is a member of many international bodies including the International Geographical Union (IGU) and the International Interdisciplinary Environmental Association. He has won awards from IGU Glasgow Conference, 2004 and the 'Sir Rees Jeffrey Road Fund' Association of European Transport Conference, Cambridge, 2001. 